\title{
AN MCE-BASED INNOVATIVE APPROACH TO EVALUATING ECOTOURISM SUITABILITY USING GIS
}

\author{
PARVIZ JOKAR ${ }^{1}$, MASOUD MASOUDI ${ }^{1 *}$, FATEMEH KARIMI ${ }^{2}$ \\ ${ }^{1}$ Department of Natural Resources and Environmental Engineering, Shiraz University, Iran. \\ ${ }^{2}$ Department of Environment, Payame Nour University of Shiraz, Iran.
}

\begin{abstract}
Geographic Information System (GIS) can be used in ecotourism as a decision support tool for sustainable tourism planning, impact assessment, visitor flow management, and tourism site selection. Therefore, this system has the potential to be widely applied in tourism. The purpose of the study was to explore the potential for ecotourism development using GIS in Sepidan region, placed in the southwestern part of Iran. An innovative method was proposed for adjusting effective parameters in evaluation of ecotourism. The methods used for evaluation comprised Boolean, current multi-criteria evaluation methods (weighted linear combination), and the proposed methods of geometric mean and its calibration. Results showed that an improved method using geometric mean $(k a p p a=0.72)$ was better than Boolean (kappa $=0.56)$ and multi-criteria evaluation (kappa $=0.59$ ) models. The calibrated geometric mean was also the best among the different models used. It should be noted that the geometric mean method was simpler than multi-criteria evaluation and did not require the weighting process.
\end{abstract}

\section{Una aproximación innovadora basada en MCE y SIG para evaluar la idoneidad del ecoturismo}

RESUMEN. Para el estudio del ecoturismo los Sistema de Información Geográfica (SIG) pueden ser utilizados como una herramienta de apoyo para tomar decisiones en la planificación del turismo sostenible, la evaluación del impacto, la gestión del flujo de visitantes y la selección de áreas turísticas. En consecuencia, este método tiene potencial para ser ampliamente aplicado a la actividad turística. El objetivo del estudio es explorar el potencial para el desarrollo del ecoturismo en la región de Sepidan, localizada en el suroeste de Irán, utilizando SIG. Un método innovador se aplicó para ajustar los parámetros útiles en la evaluación del ecoturismo. La metodología utilizada para la valoración incluyó métodos Booleanos, de evaluación multi-criterio (combinación lineal ponderada), y métodos de media geométrica y su calibración. Los resultados mostraron que un método mejorado usando la media geométrica (kappa $=0,72)$ fue más apropiado que los modelos Booleanos $(k a p p a=0,56)$ y de evaluación de criterios múltiples (kappa= 0,59). La media geométrica calibrada también fue la más idónea entre los diferentes modelos utilizados. Cabe señalar que el método de la media geométrica fue más simple que la evaluación de criterios múltiples y no requirió el proceso de ponderación.

Keyword: Ecotourism, MCE, Geometric Mean, Evaluation, Boolean.

Palabras claves: Ecoturismo, MCE, Media Geométrica, Evaluación, Booleano.

Received: 13 June 2019

Accepted: 5 June 2020

*Corresponding author: M. Masoudi. Department of Natural Resources and Environment, Shiraz University, Iran.

Email: masoudi@shirazu.ac.ir 


\section{Introduction}

For a sustainable development of a region, it is important to consider the interest of its local population. Ecotourism involves visiting the nature without damaging it and disturbing habitats. In terms of ecotourism development, researchers have recently begun to examine the role of local residents in ecotourism activities. Due to the development of alternative forms of ecotourism, these activities have attracted the interest of governments, communities, and researchers. However, environmental conservation plays an important role in ecotourism development. Many scholars now agree that ecotourism requires a two-way link between tourism and environmental conservation (Ryngnga, 2008). Therefore, ecotourism has to be developed in a planned approach where Geographical Information System (GIS) and spatial decision-making tools can act as decision support systems. Spatial decisionmaking tools can be considered as a good framework for land suitability across a landscape via the actual data, criterion outcomes, and preferences and decisions of various stakeholders and. As a result, multicriteria evaluation (MCE) methods can assess decision-making alternatives for future land-use planning (Malczewski and Rinner, 2015).

MCE is a well-known method for spatial decision making in the field of geography (Voogd, 1983; Carver, 1991; Jankowski, 1995; Thill, 1999). This method is comprised of a multitude of evaluation criteria and a preference weighting scheme to evaluate decision-making alternatives. There are various MCE methods for assessing land use suitability, including simple additive scoring (SAS) (Massam, 1988; Heywood et al., 1995), multiattribute value technique (MAVT) (Pereira and Duckstein, 1993; Keeney, 1996), multiattribute utility technique (MAUT) (Janssen and Rietveld, 1990; Keeney and Raiffa, 1993), analytic hierarchy process (AHP) (Banai, 1993; Jankowski, 1995; Najafinezhad et al., 2013; Pourkhabbaz et al., 2014), ordered weighted average (OWA) (Yager, 1988; Jiang and Eastman, 2000; Malczewski et al., 2003; Malczewski, 2006), and outranking methods (Kangas et al., 2001; Joerin et al., 2001). MCE methods determine realistic results through their spatial variations in aggregation structures and weighting schemes.

Multi-criteria decision making (MCDM) methods have significantly advanced the conventional map overlay approaches to land-use suitability analysis (Zarei and Alsheikh, 2012; Oyinloye and Kufoniyi, 2013). Generally, a problem associated with land use suitability analysis methods is they do not assure a spatial pattern with contiguity or compactness in land allocations for different land use types. Furthermore, these methods are difficult to use while land suitability maps must be consistent with ground truth, and evaluation methods should be simple.

The main objective of this paper was to implement a simple innovative and quantitative model and its comparison to the current MCE approaches for ecotourism planning.

\section{Materials and Methods}

\subsection{Study area}

With an area of 286,000 hectares, Sepidan is situated northwest of Fars province, Iran. It is located between $51^{\circ} 59^{\prime}$ east longitude and $30^{\circ} 15^{\prime}$ north latitude (Fig.1). Its ten-year average rainfall is $758 \mathrm{~mm}$, with approximately $35 \%$ and $65 \%$ of evenly distributed snow and rain, respectively. It is very cold in the winter and cool and mild in the summer. "From the contemporary technicalities of climatic classification and general populace, this city is considered cool and moist to semi-dry" (Goudarzian and Yazdani, 2015). Of note, Sepidan is one of the most well-known ecotourism locations in Iran. Figure 1 represents a sketch of the area.

The present study aimed to provide a planning method for evaluating ecotourism suitability. Hence, GIS was employed to analyze the obtained data, which were of two types, namely numerical and thematic, mainly in map format. All the relevant data were obtained from the local and main offices and institutes of the Ministries of Agriculture and Energy and thoroughly processed using GIS techniques. 
The boundaries of maps were modified by Google Earth images and Global Positioning System (GPS) tools along with field work. The criteria evaluated based on expert opinion and primary model (Makhdoum, 2006), included topography, climate, soil and geology, vegetation, water, and conservation of environment.

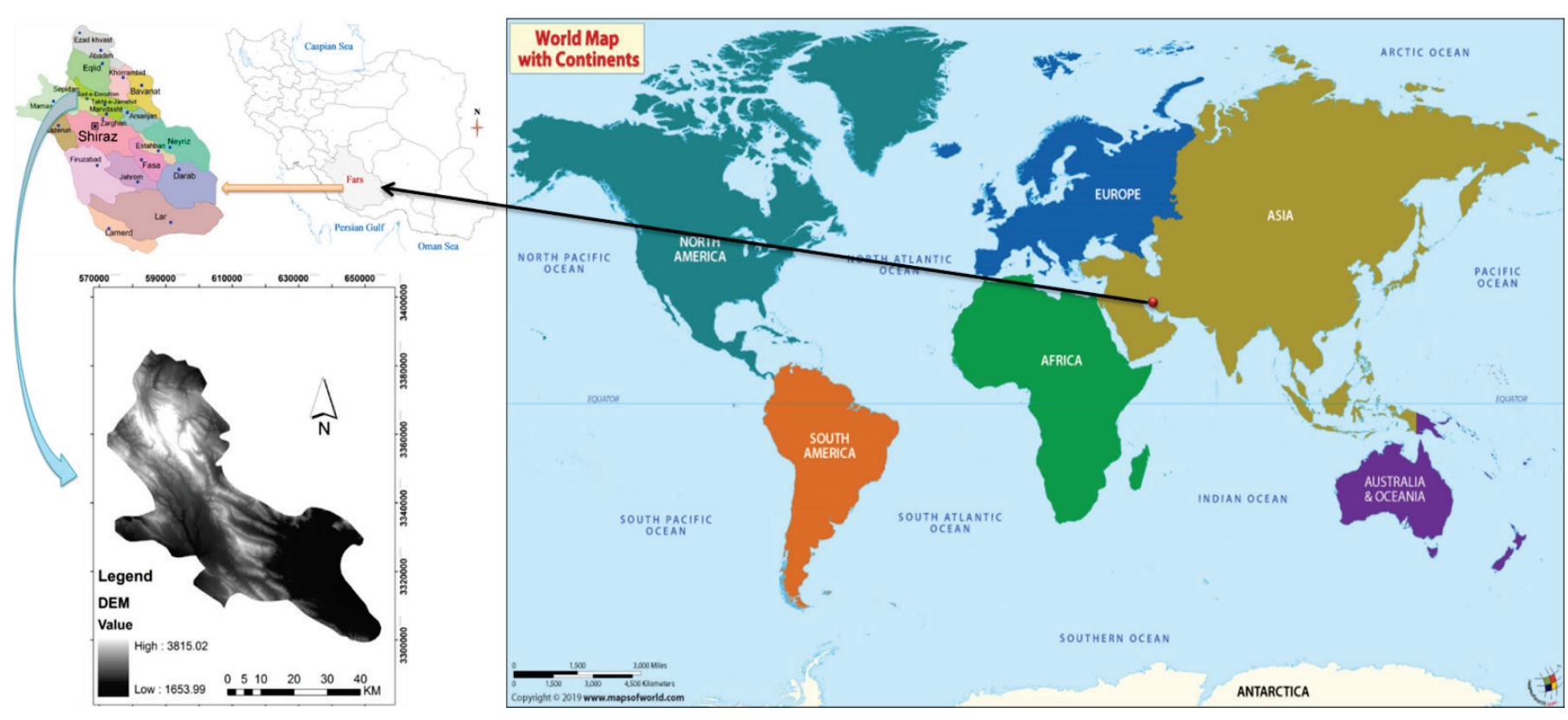

Figure 1. Location of the study area (Sepidan) in Fars Province and Iran.

\subsection{Model framework and data classification}

Model Framework involves the following steps (Fig. 2):

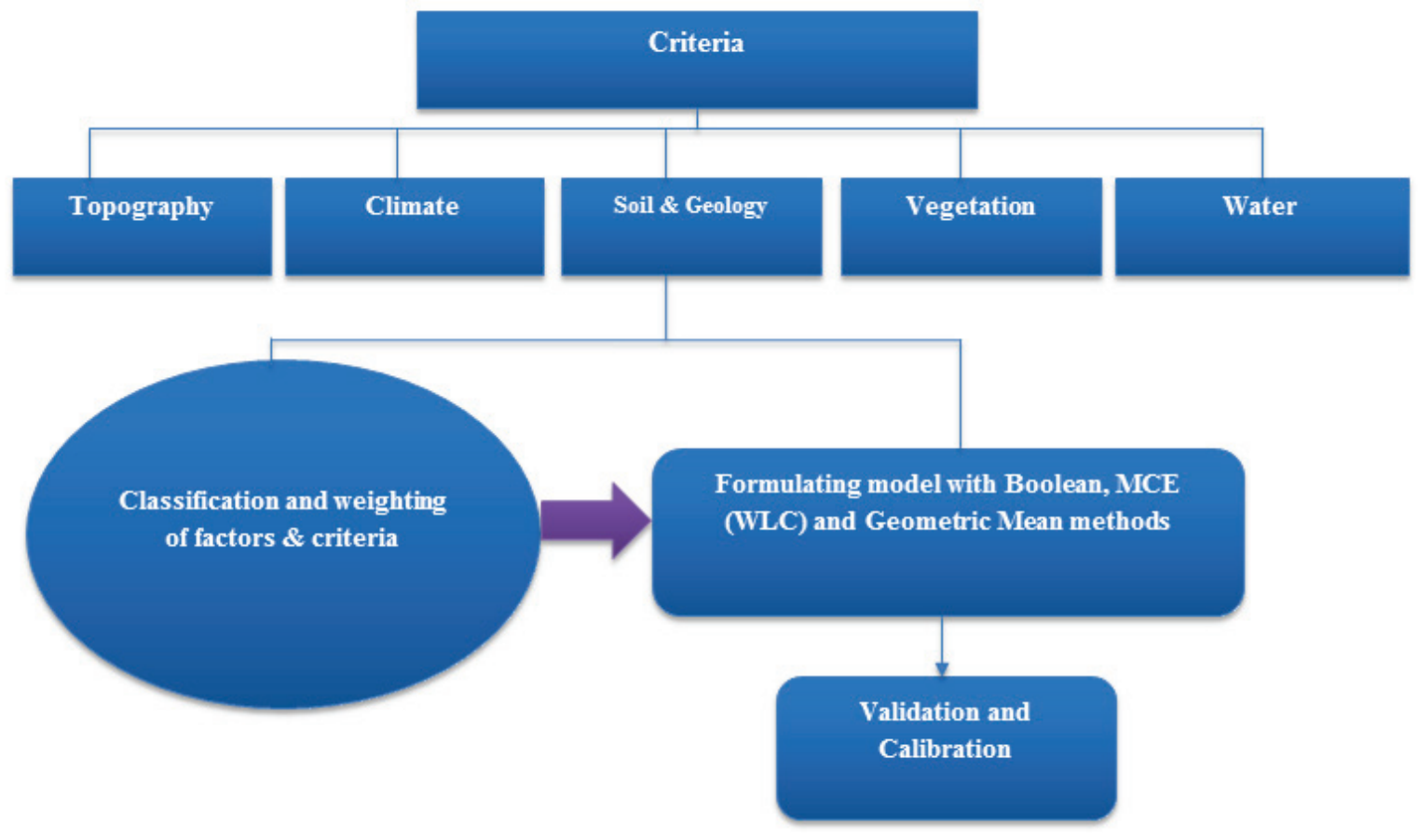

Figure 2. Platform structure of designed mode. 
i. Sampling of ecotourism regions: In this research, the data concerning the ecotourism regions of Sepidan were collected using Google Earth. These regions were modified with GPS tools during field work. In the next step, these regions were entered into ArcGIS software for analysis. In total, 187 points of ecotourism regions were systematically sampled in ArcGIS environment in order to improve and test the model.

ii. Primary model: The Iranian ecological model (Makhdoum, 2006) was run for the study area. It is composed of three classes pertaining to the ecological potentials of ecotourism and their associated capability class numbers. Class 1 is considered as suitable, class 2 is moderate, and class 3 is poor and non-suitable.

iii. Improved model: The Iranian ecological model and its indicators were improved based on the existing models (Makhdoum, 2006; Makhdoum et al., 2009; Mahdavi et al., 2015; Bunruamkaew and Murayama, 2011; Anane et al., 2012; Chakrabarty, 2011). Certain parameters such as soil depth were further ignored to increase the model efficiency (Jokar and Masoudi, 2016). As a result, effective parameters in the improved model are shown with an asterisk in Table 1. It should be noted that the next stages of evaluation were based on this model.

Table1. The indicators used in the model of land evaluation for Ecotourism (3classes)

\begin{tabular}{|c|c|c|c|c|}
\hline CRITERIA & INDICATOR & Highly Suitable (2) & Moderately Suitable (1) & $\begin{array}{c}\text { Poor \& Not Suitable } \\
(0)\end{array}$ \\
\hline TOPOGRAPHY & *Slope $(\%)$ & $0-15$ & $15-30$ & $>30$ \\
\hline \multirow{2}{*}{ CLIMATE } & $\begin{array}{c}\text { *Number of sunny days } \\
\text { (in spring \& summer months) }\end{array}$ & $>15$ & $7-15$ & $<7$ \\
\hline & $\begin{array}{l}* \text { Average of temperature }\left({ }^{\circ} \mathrm{C}\right) \\
\text { (in spring \& summer seasons) }\end{array}$ & $21-24$ & $18-21,24-30$ & $>30,<18$ \\
\hline \multirow{5}{*}{ SOIL } & *Texture & Usually moderate & Coarse, light, heavy & Very heavy \\
\hline & Depth(cm) & Deep & Semi deep & Shallow \\
\hline & $*$ Drainage $(\mathrm{cm} / \mathrm{hr})$ & Good (2-6) & \begin{tabular}{|c|} 
Moderate to poor $(0.1-2,6-$ \\
$25)$
\end{tabular} & Incomplete $(<0.1,>25)$ \\
\hline & Evolution (Structure) & Perfect (granular) & Moderate & Low \\
\hline & Fertility (organic matter \%) & Good, Moderate $(>1)$ & Low (1) & Very Low $(<1)$ \\
\hline GEOLOGY & *Lithology & $\begin{array}{c}\text { pyroclastic rocks, Granite } \\
\text { Ophiolite of melange color, } \\
\text { sand dunes, continental shelf } \\
\text { sediments }\end{array}$ & $\begin{array}{c}\text { Limestone and Dolomite, } \\
\text { sandstone, loess, schist and } \\
\text { gneiss and amphibolite, } \\
\text { quartzite, alluvial fans, } \\
\text { flood plain } \\
\end{array}$ & $\begin{array}{c}\text { marl, Shale, Clay } \\
\text { Stone, Conglomerate, } \\
\text { Salt domes, gypsum } \\
\text { dome, calcite and } \\
\text { dolomite marble } \\
\end{array}$ \\
\hline VEGETATION & *Vegetation type & $\begin{array}{l}\text { Forest lands with canopy cover } \\
\text { of } 50-80 \%\end{array}$ & $\begin{array}{l}\text { Forest lands with canopy } \\
\text { cover of } 5-50 \%\end{array}$ & $\begin{array}{l}\text { Poor Rangelands, } \\
\text { Forest lands with } \\
\text { canopy cover } \\
>80 \% \text {, Desert }\end{array}$ \\
\hline WATER & $\begin{array}{c}* \text { Quantity of water } \\
\text { For everyone (Lit/day) }\end{array}$ & $>40$ & $12-39.9$ & $<12$ \\
\hline CONSERVATION & $*$ Protected area & $\begin{array}{c}\text { Forest park of Natural and } \\
\text { planted, Nature Park, National } \\
\text { Park, Protected Area, } \\
\text { Biosphere Reserve, World } \\
\text { Heritage, Historical artefacts } \\
\text { and national and pilgrimage } \\
\end{array}$ & - & $\begin{array}{l}\text { Reserve forest, } \\
\text { Wildlife Sanctuary, } \\
\text { National natural } \\
\text { monuments }\end{array}$ \\
\hline
\end{tabular}

iv. Evaluation of the final model with mathematic methods: To evaluate the model, two basic methods (Boolean and MCE) and one proposed method (Geometric Mean) were used:

- Boolean: Boolean algebra is a mathematical system for the manipulation of variables that can have one of two values represented by: True or False, Yes or No, On or Off, 1 or 0. Boolean logic has three basic operators: Intersection (the logical term AND), Union (the logical term OR) and Inverse (the logical term NOT). These Boolean 
operators use integers or terms such as "True" and "False" as an input raster on a cellby-cell basis. Output values of True are (1) and those of False are (0) (Froja, 2013). In this paper, the primary and final models were evaluated based on the Boolean method.

- MCE (WLC) method: In the present research, MCE was used to assess the ecotourism. Accordingly, 35 questionnaires were given to experts in the field of ecotourism for weighting different criteria and factors, which was done via Expert Choice software. Table 2 shows the weight of criteria and factors with consistency ratio $(\mathrm{CR})<0.1$. Afterwards, WLC (weighted linear combination) method was used for the weighted overlay of the input data layers. With the weighted linear combination, the factors were primarily combined through applying a weight to each factor and criteria, followed by a summation of the results to yield a suitability map (Equations 1 and 2). Finally, the constraint factors $\left(\mathrm{C}_{\mathrm{i}}\right)$ were multiplied in the map (Fallahshamsi, 2004; Ghadimi et al., 2011):

Equation $1=\left[\left(\mathrm{W}_{1} \times\right.\right.$ factor 1$)+\left(\mathrm{W}_{2} \times\right.$ factor 2$) \ldots+\left(\mathrm{W}_{\mathrm{n}} \times\right.$ factor $\left.)\right] \times \mathrm{C}_{\mathrm{i}}$

$$
\text { Equation } 2=\left[\left(\mathrm{W}_{1} \times \text { Criteria1 }\right)+\left(\mathrm{W}_{2} \times \text { Criteria2 }\right) \ldots+\left(\mathrm{W}_{\mathrm{n}} \times \text { Criteria }\right)\right] \times \mathrm{C}_{\mathrm{i}}
$$

Table 2. Weight of criteria and indicators by AHP.

\begin{tabular}{|c|c|c|c|}
\hline Criteria & Criteria Weight & factor & factor Weight \\
\hline Topography & 0.16 & Slope (\%) & 1 \\
\hline \multirow{2}{*}{ Climate } & \multirow{2}{*}{0.13} & $\begin{array}{c}\text { Number of sunny days (in spring \& } \\
\text { summer months) }\end{array}$ & 0.5 \\
\hline & & $\begin{array}{c}\text { Average of temperature }\left({ }^{\circ} \mathrm{c}\right) \text { (in spring } \\
\& \text { summer seasons) }\end{array}$ & 0.5 \\
\hline \multirow{3}{*}{ Soil and Geology } & \multirow{3}{*}{0.16} & Texture & 0.33 \\
\hline & & Drainage $(\mathrm{cm} / \mathrm{hr})$ & 0.37 \\
\hline & & Lithology & 0.3 \\
\hline Vegetation & 0.18 & Vegetation type & 1 \\
\hline Water & 0.19 & $\begin{array}{c}\text { Quantity of water } \\
\text { For everyone (Lit/day) }\end{array}$ & 1 \\
\hline Conservation & 0.18 & Protected area & 1 \\
\hline \multicolumn{4}{|c|}{ CR (Consistency Ratio) $<0.1$} \\
\hline
\end{tabular}

- Geometric mean method (proposed): In the geometric mean method (such as MEDALUS model (Kosmas et al., 1999)), every index (Table 1) was given a weight from 0 (non-suitability of ecological conditions for ecotourism use such as deserts) to 2 (the most suitable ecological condition for ecotourism). Next, every criterion was calculated based on the geometric mean of indicators according to Equation 3:

$$
\text { Equation 3: Criterion_X }=\left[\left(\text { Layer-1) } \times(\text { layer-2) } \times \ldots \times(\text { Layer-n })]^{1 / n}\right.\right.
$$

where Criterion_ $\mathrm{X}$ is a defined criterion, Layer is an indicator map of the criterion, and $\mathrm{n}$ is the number of used indicators. The criteria were then multiplied through geometric mean (Equation 4):

$$
\text { Equation 4: Final Criterion }=\left[\left(\text { Layer-1) } \times(\text { layer-2) } \times \ldots \times(\text { Layer-n })]^{1 / n}\right.\right.
$$


where Final Criterion is the final layer of ecological capability, and $\mathrm{n}$ is the number of used criteria. For ecotourism planning, qualitative and suitability classes of ecological capability were identified by use of GIS (Jokar et al., 2015) (Table 3).

Table 3. Suitability classes in the Capability Maps and models for 3 classes uses regarding the scores of polygons.

\begin{tabular}{|c|c|c|c|}
\hline \multirow{2}{*}{ Their score } & \multicolumn{3}{|c|}{ Suitability classes } \\
\cline { 2 - 4 } & Good (1) & Moderate (2) & Poor \& Not suitable (3) \\
\cline { 2 - 4 } & $1.5-2$ & $0.5-1.5$ & $<0.5$ \\
\hline
\end{tabular}

v. Validation and Calibration: The accuracy of the identified classes was assessed by detailed ground reality (Makhdoum et al., 2009). For this purpose, ecotourism regions (as suitable classes of ground reality) were primarily created by use of Google Earth, GPS, and field work. After that, the samples of these areas were systematically gathered by "Create Fishnet" algorithm in ArcGIS 9.3 environment (Fallahshamsi, 1997). Of note, sampling of suitable classes (ecological and socioeconomical) of ground reality were more than others (such as moderate and non-suitable classes), as shown in Figure 3 (Fallahshamsi, 1997). This means the current ecotourism areas were sampled more than those with less suitability for ecotourism. In fact, these regions were selected as ground reality and had to be compared with potential conditions. Afterwards, these points (ground reality) were overlaid to the land capability maps. The obtained results are shown in Table 4 (error matrix or agreement matrix), and quantitative indices such as overall accuracy, kappa coefficient, and in class coefficient were calculated.

vi.
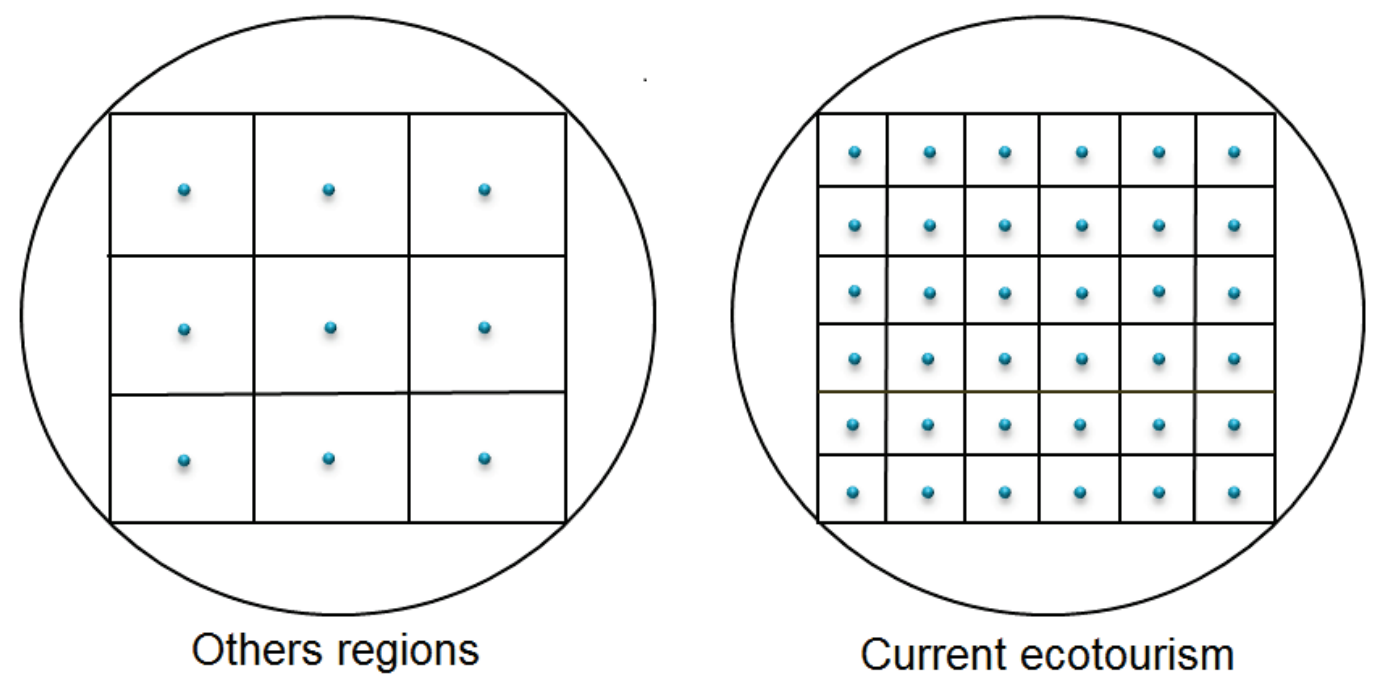

Figure 3. Sampling of suitable classes of ground reality comparing to other. 
Table 4. Error Matrix for ecotourism use in study area.

\begin{tabular}{|c|c|c|c|c|}
\hline Model & \multicolumn{4}{|c|}{ Ground Reality } \\
\hline \multirow{4}{*}{ Classify } & Class & $\begin{array}{c}\text { Current } \\
\text { ecotourism }\end{array}$ & $\begin{array}{c}\text { Forest lands with canopy cover 5-50\% } \\
\text { (exception current ecotourism and Non- } \\
\text { suitable) }\end{array}$ & $\begin{array}{c}\text { Poor } \\
\text { Rangelands, } \\
\text { Desert }\end{array}$ \\
\cline { 2 - 5 } & Suitable & $*$ & & \\
\cline { 2 - 6 } & Moderate & & $*$ & $*$ \\
\cline { 2 - 6 } & Non-suitable & & 440 & 469 \\
\hline
\end{tabular}

A particular aspect of the proposed accuracy assessment is that capability classes indicate the relative rather than the absolute values of capability for a particular area (Sepehr et al., 2007). Omission and commission errors were used to increase the accuracy and calibrate the model. Hence, according to these errors in the geometric mean method, the quantitative ranges of suitability classes (Table 3 ) were slightly changed. This kind of calibration has been performed in other classifications such as MEDALUS method (Kosmas et al., 1999). In the present research, class 1 ranged from 1-1.47 to 2.

\section{Results and Discussion}

Using ArcGIS software, the geospatial data were processed and the Boolean, MCE, and the proposed methods were implemented. The output maps obtained for ecotourism land capability are presented in Figure 4. The maps include primary and improved models by Boolean algebra, MCE, geometric mean, and calibration of geometric mean. Figure 5 also presents land percentage under different capability classes in different maps and the flexibility of each model. For instance, in Boolean methods, most regions tended towards the weaker classes while in MCE methods, the opposite was the case. However, the proposed methods (geometric mean and calibration of geometric mean) showed a balanced state between the foregoing models. They showed all three classes in the maps and had more agreement with the ground reality of the region. According to Figures 4 and 5, the primary model (Iranian ecological model) with Boolean has the least suitable class $(0.018 \%)$. In this method, the most widespread area was in poor and none-suitable class (79.63\%), showing the highest percentage for this class among all methods. Its improved method (with Boolean view) showed a slight increase in good class $(0.08 \%$ of region). The moderate class increased $(56.05 \%)$ and the none-suitable class $(43.87 \%)$ decreased compared to the primary model. Results showed that among the evaluation methods, the averaging methods (MCE, geometric mean, and calibration) had a better classification compared with Boolean methods. It should be noted that geometric mean and its calibration were the most optimal methods, hence useful and flexible for ecotourism purposes. The suitability of each class has to be accurately determined. Table 5 shows the results related to the number of accuracy indices for all methods used. As observed, the method improved using geometric mean was better than Boolean and MCE models, calibrated geometric mean was the best, and primary model (Iranian ecological model) had the least accuracy. 


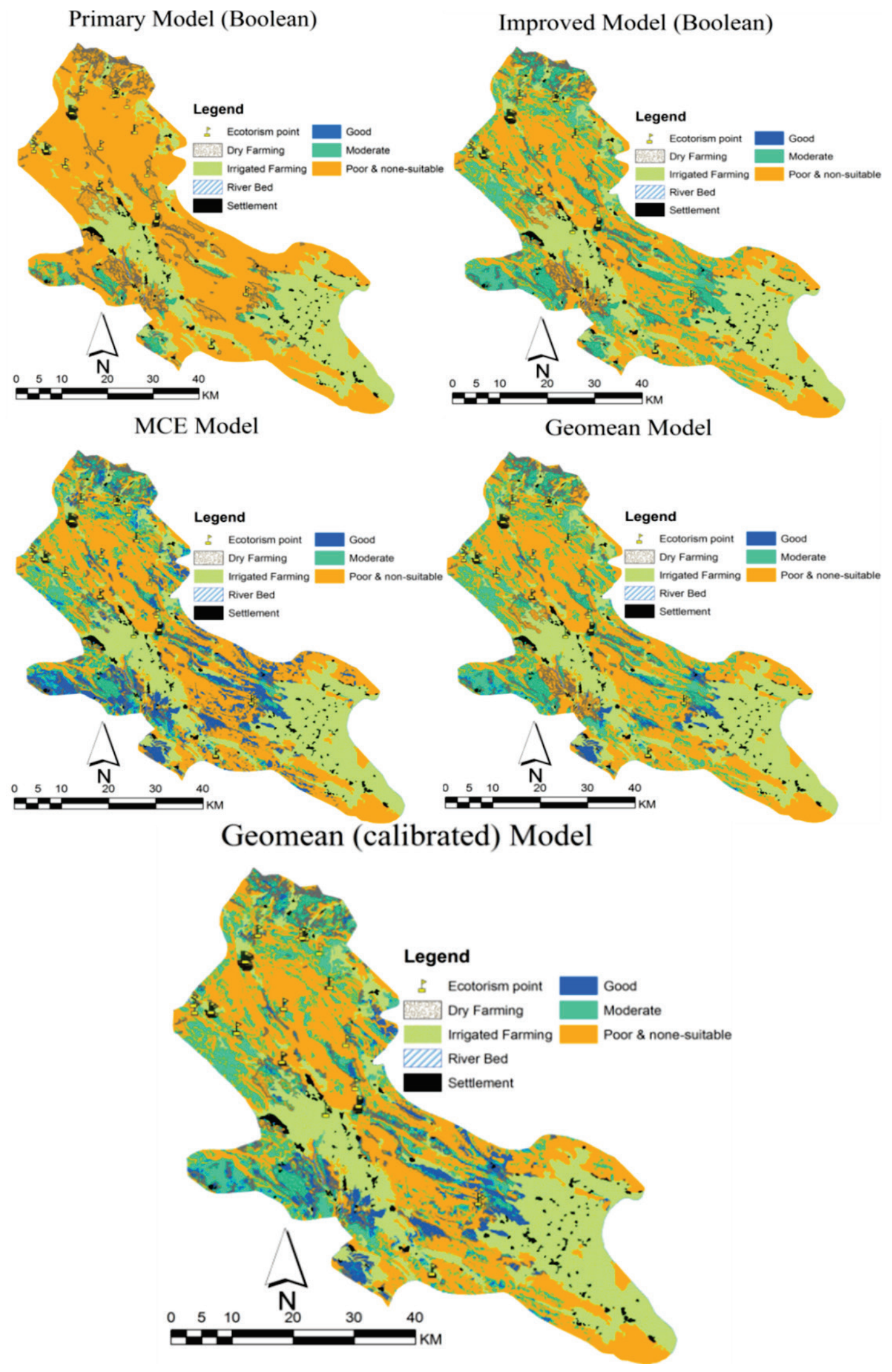

Figure 4. Ecological capability maps prepared for used models. 


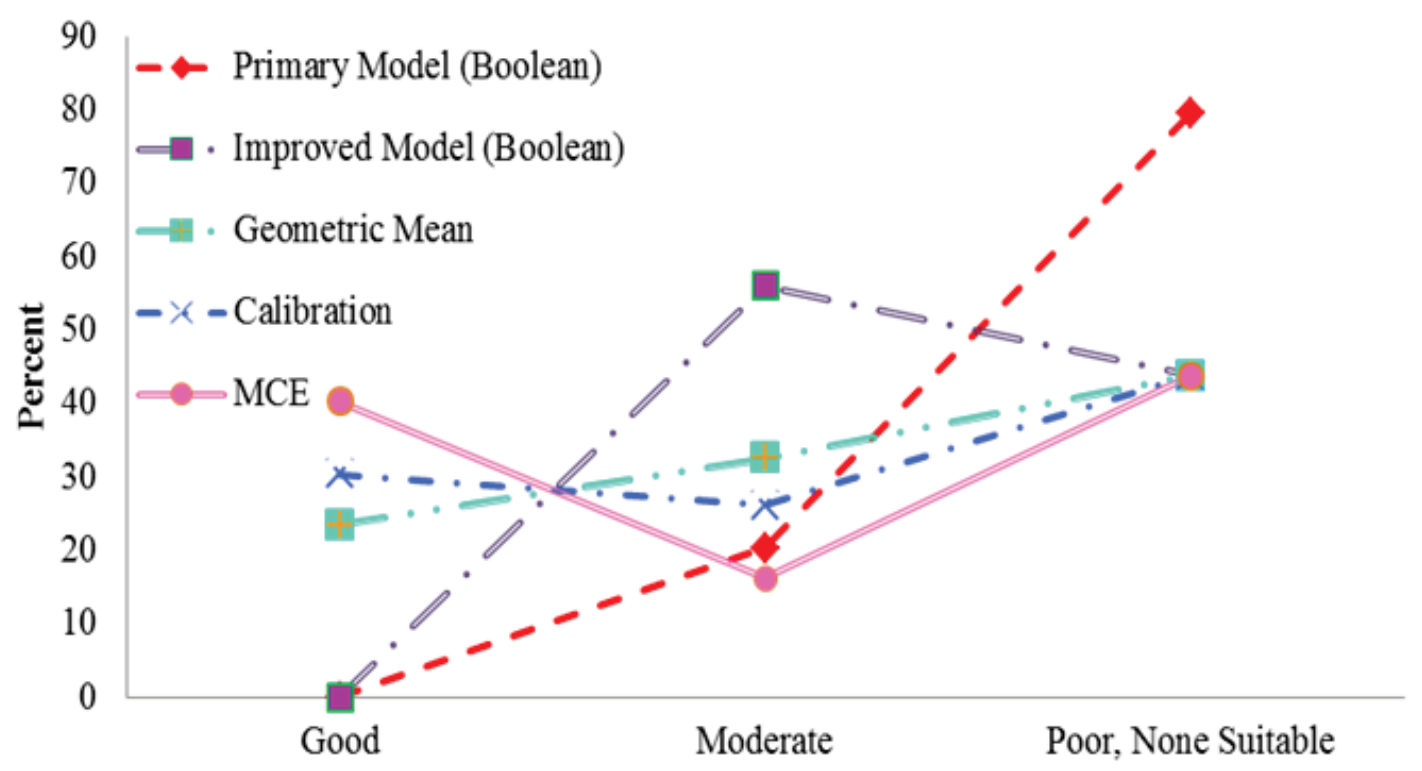

Figure 5. Percent of land under different capability classes for different methods of ecotourism use.

Table 5. Overall Accuracy, Inclass and Kappa Coefficients in the used models.

\begin{tabular}{|c|l|c|c|c|c|c|}
\hline \multirow{2}{*}{ Land Use } & \multirow{2}{*}{ Index } & Podel & Primary & \multicolumn{4}{|c|}{ Improved } \\
\cline { 3 - 7 } & & Boolean & Boolean & MCE & Geometric & Calibration \\
\hline \multirow{3}{*}{ Ecotourism } & Overall Accuracy & 54 & 74 & 73 & 81 & 82 \\
\cline { 2 - 7 } & Kappa Coefficient & 0.2 & 0.56 & 0.59 & 0.7 & 0.72 \\
\cline { 2 - 7 } & Inclass Coefficient & 0 & 0 & 0.76 & 1.14 & 1.35 \\
\hline
\end{tabular}

\section{Conclusion}

This study successfully implemented a GIS-based method as an advanced and more precise MCE approach to evaluating the capability and suitability of ecotourism area. The proposed model can be applied to all types of study areas. The geometric mean method is simpler than MCE and does not require weighting process whereas most studies (Kangas et al., 2001; Joerin et al., 2001; Najafinezhad et al., 2013; Pourkhabbaz et al.,2014) have assessed land capability based on subjective opinions. Also, among the models generated by Boolean, MCE (WLC), and geometric mean methods, the results showed that the primary model (Iranian ecological model) by Boolean had the lowest accuracy, which is line with Najafinezhad et al. (2013) and Fallahshamsi (2004). However, after modifying the model (by the same Boolean method), the results and accuracy were further improved (Table 5). Next, the evaluation methods of the improved model were changed by averaging methods (MCE, geomean and calibration, Table 5). Results (Table 5) showed that these methods had a higher accuracy compared with Boolean methods (in accordance with Fallahshamsi, 2004; Ghadimi et al., 2011; Najafinezhad et al., 2013; Elaalem et al., 2010). Geometric mean method had a higher accuracy than MCE method, and its calibration was the most optimal method for ecotourism planning as man-made use. Additionally, compared to Boolean model, geometric mean reduced the dependency on indicator numbers (like soil with higher indicators compared to those criteria that include fewer indicators such as topography). Hence, this point can be considered by geometric mean and its type of evaluation. Therefore, for example, climate and topography with only two indicators had the same weight as soil factor with more indicators, which is in good agreement with other studies (Jokar et al., 2015; Jokar and Masoudi, 2016). 
Due to the importance of natural hazards, parameters such as drought and climate change should be considered in future research. It is recommended that the results of this study be considered by managers and other stakeholders in management planning processes.

\section{Acknowledgement}

Especial thanks to the official organizations of Iran (especially Shiraz University) for providing the data, maps and reports for this project.

\section{References}

Anane, M., Bouziri, L., Limam, A., Jellali, S. 2012. Ranking suitable sites for irrigation with reclaimed water in the Nabeul-Hammamet region (Tunisia) using GIS and AHP-multicriteria decision analysis. Resources, Conservation and Recycling 65, 36-46. https://doi.org/10.1016/j.resconrec.2012.05.006

Banai, R. 1993. Fuzziness in geographic information systems: contributions from the analytic hierarchy process. International Journal of Geographical Information Systems 7(4), 315-329. https://doi.org/10.1080/02693799308901964

Bunruamkaew, K., Murayama, Y. 2011. Site suitability evaluation for ecotourism using GIS \& AHP: A case study of Surat Thani Province, Thailand. Procedia Social and Behavioral Sciences 21: 269 - 278. https://doi.org/10.1016/j.sbspro.2011.07.024

Carver, S.J. 1991. Integrating multi-criteria evaluation with geographical information systems. International Journal of Geographical Information Systems 5(3), 321-339. https://doi.org/10.1080/02693799108927858

Chakrabarty, A. 2011. Ecotourism Development and Security Restructuring: A GI Based Planning for Peaceful Dissuasion of Anarchism in Forest Provinces of India. Procedia Social and Behavioral Sciences 21, 108-115. https://doi.org/10.1016/j.sbspro.2011.07.006

Elaalem, M., Comber, A., Fisher, P. 2010. Land Suitability Analysis comparing Boolean logic with fuzzy analytic hierarchy process. Accuracy 2010 Symposium, July 20-23, Leicester, UK. pp. 245-247.

Fallah Shamsi, S.R. 1997. Accuracy assessment of satellite-based maps using sampling. M.Sc Dissertation, Faculty of Natural Resources, University of Tehran, Iran, pp. 86. (In Persian).

Fallahshamsi, H.R. 2004. Economic Evaluation of Different Land uses in Kalibar - chai Forest -covered Watershed, Using Linear Programming and Geographical Information Systems, Ph.D. Thesis Report, Natural Resource Faculty, Tehran University, Karaj. [In Persian]

Froja, N.M. 2013. Fuzzy-GIS Development of Land Evaluation System for Agricultural Production in North West Libya. PhD thesis, School of the Built Environment, Heriot-Watt University.

Ghadimi, M., Hosseini, M., Pourghasemi, H.R., Moradi, H.R. 2011. Protection Modeling of Manesht and Ghalarang Protected Areas Using Fuzzy logic. Environmental Sciences, 8: 85-106. [In Persian]

Goudarzian, P., Yazdani, M.R. 2015. Climate diversity in line with agroforestry systems: studying technicalities of agroforestry systems and allied components in two diverse climatic regions (Warm climate vs. cold climate) (Case study: Kazeroun \& Sepidan in Fars Province, I. R. Iran). Desert 20(2): 157-166.

Heywood, I., Oliver, J., Tomlinson, S. 1995. Building an exploratory multi-criteria modelling environment for spatial decision support. In P. Fisher (Ed.) Innovations in GIS, Taylor and Francis, London, UK, pp. 127-136.

Jankowski, P. 1995. Integrating geographical information systems and multiple criteria decision-making methods. International Journal of Geographical Information Systems 9(3), 251-273. https://doi.org/10.1080/02693799508902036

Janssen, R., Rietveld, P. 1990. Multicriteria analysis and geographical information systems: an application to agricultural land use in the Netherlands. In H. J. Scholten and J. C. H. Stillwell (Eds.) Geographical information systems for urban and regional planning, Kluwer Academic Publishers, Dordrecht, The Netherlands, pp. 129-139. 
Jiang, H., Eastman, J. R. 2000. Application of fuzzy measures in multi-criteria evaluation in GIS. International Journal of Geographical Information Science 14(2), 173-184. https://doi.org/10.1080/136588100240903

Joerin, F., Theriault, M., Musy, A. 2001. Using GIS and outranking multicriteria analysis for land-use suitability assessment. International Journal of Geographical Information Science 15(2), 153-174. https://doi.org/10.1080/13658810051030487

Jokar, P., Masoudi, M. 2016. Land Suitability for Urban and Industrial Development by a Proposal Model, Case Study: Jahrom Township, Iran. Journal of Environmental Studies 42, 135-149.

Jokar, P., Masoudi, M., Fallah Shamsi, S.R., Afzali, S.F. 2015. Developing a Model for Ecological Capability Evaluation of Ecotourism (A Case Study: Jahrom Township, Iran). International Journal of Scientific Research in Environmental Sciences 3(1): 1-8. https://doi.org/10.12983/ijsres-2015-p0001-0008

Kangas, A., Kangas, J., Pykäkäinen, J. 2001. Outranking methods as tools in strategic natural resources planning. Silva Fennica 35(2), 215-227. https://doi.org/10.14214/sf.597

Keeney, R.L. 1996. Value-focused thinking: identifying decision opportunities and creating alternatives. European Journal of Operational Research 92, 537-549. https://doi.org/10.1016/0377-2217(96)00004-5

Keeney, R.L., Raiffa, H. 1993. Decisions with Multiple Objectives: Preferences and Value Tradeoffs (2nd Edition). Cambridge: Cambridge Press.

Kosmas, C., Poesen, J., Briassouli, H. 1999. Key indicators of desertification at the Environmentally Sensitive Areas (ESA) scale, The Medalus Project: Mediterranean Desertification and Land Use. Manual on Key Indicators of Desertification and Mapping Environmentally Sensitive Areas to Desertification. Project report. European Commission.

Mahdavi, A., Niknejad, M., Karami, O. 2015. A fuzzy multi-criteria decision method for locating ecotourism development. Caspian J. Env. Sci. 13 (3), 221-236.

Makhdom, M. 2006. Principles of Land use planning. 7th ed, University of Tehran.

Makhdom, M., Darvishsefat, A., Jafarzadeh, H., Makhdom, A. 2009. Environmental Evaluation and Planning by Geographic Information System. 4th ed, University of Tehran.

Malczewski, J., Rinner, C., 2015. Multicriteria Decision Analysis in Geographic Information Science. Springer, New York, p. 1-331.

Malczewski, J. 2006. Ordered weighted averaging with fuzzy quantifiers: GIS-based multicriteria evaluation for land-use suitability analysis. International Journal of Applied Earth Observation and Geoinformation 8(4), 270-277. https://doi.org/10.1016/j.jag.2006.01.003

Malczewski, J., Chapman, T., Flegel, C., Walters, D., Shrubsole, D., Healy, M.A. 2003. GIS-multicriteria evaluation with ordered weighted averaging (OWA): case study of developing watershed management strategies. Environment and Planning A 35(10), 1769-1784. https://doi.org/10.1068/a35156

Massam, B.H. 1988. Multi-criteria decision making (MCDM) techniques in planning. Progress in Planning 30(1), 1-84. https://doi.org/10.1016/0305-9006(88)90012-8

Najafinezhad, A., Pishdad Soleimanabad, L., Salmanmahini, A. 2013. Comparison of the efficiency of systematic and multi objective land allocation methods for land use planning using Geographic Information System. Journal of Applied RS \& GIS Techniques in Natural Resource Science 4, 1-11. [In Persian]

Oyinloye, M., Kufoniyi, O. 2013. Application of IKONOS Satellite Images in Monitoring of Urban Landuse Change in Ikeja, GRA, Lagos, Nigeria. International Journal of Engineering Science Invention 2, 1-10.

Pereira, J.M.C., Duckstein, L. 1993. A multiple criteria decision-making approach to GIS-based land suitability evaluation. International Journal of Geographical Information Systems 7(5), 407-424. https://doi.org/10.1080/02693799308901971

Pourkhabbaz, H.R., Javanmardi, S., Faraji Sabokbar, H.A. 2014. Suitability Analysis for Determining Potential Agricultural Land Use by the Multi-Criteria Decision-Making Models SAW and VIKOR-AHP (Case study: Takestan-Qazvin Plain). J. Agr. Sci. Tech. 16, 1005-1016. 
Jokar et al.

Ryngnga, P.K. 2008. Ecotourism Prioritization: A Geographical Information System Approach. South Asian Journal of Tourism and Heritage 1, 49-56.

Sepehr, A., Hassanli, A.M., Ekhtesasi, M.R., Jamali, J.B. 2007. Quantitative assessment of desertification in south of Iran using MEDALUS method. Environ. Moni.t Assess. 134, 243-254. https://doi.org/10.1007/s10661-0079613-6

Thill, J.C. 1999. Multicriteria decision-making and analysis: a geographic information sciences approach. Ashgate, New York, USA.

Voogd, H. 1983. Integrating multi-criteria evaluation with geographical information systems. Taylor \& Francis, London, UK.

Yager, R. 1988. On Ordered weighted averaging aggregation operators in multicriteria decision making. IEEE Transactions on Systems, Man, and Cybernetics 18(1), 183-190. https://doi.org/10.1109/21.87068

Zarei, R., Alsheikh, A. 2012. Modeling of Urban Development Using CA and Genetic Algoritm (A Case Study: Shiraz City). Urban Planning 3, 1-16. [In Persian] 